\title{
CULTURAL INTELLIGENCE AND NETWORK ORGANIZATIONS IN SOCIETY: CASE OF TEHRAN NEIGHBORHOOD COUNCILS
}

\author{
Yashar Salamzadeh ${ }^{9}$, Aidin Salamzadeh ${ }^{10}$, Mirjana Radovic \\ Markovic ${ }^{11}$
}

\begin{abstract}
Network communications is one of the modern ideas in the field of organizational behavior. On the other hand, the ability to communicate with employees and understand the cultural differences between them in a multicultural environment is one of the key skills that managers and employees need them in the nowadays organizations. These skills are introduced as cultural intelligence in organizations that have ability to respond to many challenges in multicultural environments. This article was aimed to analysis the relationship between cultural intelligence and network communication. These questionnaires were distributed between 134 members at the Tehran neighborhood councils. In order to analyzing data and concluding results, SPSS, and then Pearson correlation test were used. The research was done based on structural equation modeling (SEM). The result indicated that there was significant positive relationship between cultural intelligence and network communication. Also there was significant positive relationship between each dimension of cultural intelligence and network communication. Findings show that cultural intelligence is a basic factor in network communication and confirm the main hypothesis of this study which represents the existence of a positive and meaningful relation between cultural intelligence and network communication. Furthermore, the results show that considering this kind of intelligence, especially in network organizations which has a high ethnic and cultural variety, could be very useful for improve employees and managers communications.
\end{abstract}

KEYWORDS: cultural intelligence, communication, network organizations, network communication

JEL: D83, D85, Z13

UDC: 005.336.5:005.57

005.72:004

\footnotetext{
${ }^{9}$ International University of Iran, Karaj, Iran,e-mail: yasharsalamzadeh@gmail.com

${ }^{10}$ Faculty of Entrepreneurship, University of Tehran,Iran,e-mail: Salamzadeh@ut.ac.ir

${ }^{11}$ Faculty of Business Economics and Entrepreneurship,Belgrade,Serbia,mail:e-

mradovic@gmail.com
} 


\section{Introduction}

Nowadays most of companies in the twenty first century are multicultural. This results in several dyadic relationships where the cultures of the members differ significantly. The difference may be in: (i) language, (ii) ethnicity, (iii) religion, (iv) politics, (v) social class, etc. (Triandis, 2006; Gorji, Ghareseflo, 2011; Radovic-Markovic et al.,,2014;Kanten, 2014). Cultural intelligence (CI) is conceptualized as four different intelligences residing within an individual, which are: (i) meta-cognitive, (ii) cognitive, (iii) motivational, and (iv) behavioral (Earley, Ang, 2003; Keung, Rockinson-Szapkiw, 2013). Meta-cognitive CI reflects the processes individuals use to gain and comprehend cultural knowledge. Cognitive CI is general knowledge and knowledge structures about culture. Motivational CI is amount and direction of energy applied towards learning about and functioning in cross-cultural situations. Finally, behavioral CI is the capability to exhibit appropriate verbal and non-verbal actions when interacting with people from different cultures (Ang et al., 2006; Alidoust and Homaei, 2012). Network organizations could bring individuals together who were previously unknown to one another (Fox, 2008). Moreover, network organizations can involve individuals who have different cultures, first languages, social concerns, genders, personality types, or even work experiences. Moreover, CI in network organizations especially on communications is so effective and significant. Network organizations are characterized by flexibility (Nohria, Eccles, 2000), decentralization (Arquilla, Ronfeldt, 2001), differentiation (Baker, 1992), diversity (Ibarra, 1992), lateral cross-functional ties (Baker, 1992) and redundancy (Ronfeldt, Arquilla, 2001).

Moreover, social entities and communities are of paramount importance. One could consider that in today's societies, most of the social dilemmas are handled by social communities. In Iran, the history of social activities goes back to thousands of years ago (Daryani et al., 2011; Salazmadeh et al., 2011a, b, c, 2013). But, today, neighborhood councils play a very significant role in different cities. Then, the aim of this paper is surveying the effect of CI on communication in Tehran neighborhood councils with introducing the concepts of CI based on the theoretical overview and empirical studies. For this purpose, the researchers proposed one main hypothesis and four sub-hypotheses. Thus, the findings are discussed, and the paper concludes with some remarks and directions for future research.

\section{Literature review}

\section{Cultural intelligence (CI)}

CI or CI has a variety of meanings and definitions which could be seen as complementary to one another. CI is defined as an individual's capability to function and manage effectively in culturally diverse settings or environments (Ang et al., 2007; RadovicMarkovic,et.al.2014). One of the most important challenges of managers and employee, at international environments, is that they could become sure to realize different views completely. Offerman and Phan (2002) defined CI as a "intelligence at environment" or the ability to operate within and across a variety of culturally diverse environments, in which individuals are prone to face a variety of values, customs, (pre)assumptions and expectations that are essentially different from their own (Moody, 2007). 
$\mathrm{CI}$ is the ability and capability of one individual in effective performance at different positions in different cultures. It prepares insights about individual's abilities and capabilities to overcome multi-cultural situations, involving at inter-cultural trades and performance at different working groups (Lugo, 2007). As mentioned earlier, CI is composed of four parts: (i) meta-cognition, (ii) cognition, (iii) motivation, and (iv) behavior. High level individuals use all these four parts and are more prone to succeed (Ang et al., 2007; Earley, Peterson, 2004; Ng,Earley, 2006). According to these four elements, the following propositions are proposed.

\section{Meta-cognition}

Meta-cognition is defined as an individual's knowledge or control over cognitions that leads to deep information processing (Ford et al., 1998; Ang et al., 2007). It is focused on the ability to process information stored in memory in order to guide attention, make sense, process the knowledge, as well as the individual's goals, emotions, motives, and external stimuli. It is not sufficient to simply know oneself in order to obtain high level of metacognition; individuals must be able to be flexible in their self-concept, and have the ability to integrate new components into their self-concept (Earley, Ang, 2003; Thomas, 2006).

H1: Meta-cognition has a significant relationship with communications of Tehran Neighborhood councils

\section{Cognition}

Cognition refers to application of self knowledge, the social environment, and processing information (Earley, Ang, 2003). Basically, it involves the general knowledge about the structures of a culture (Earley and Ang, 2003; Ng and Earley, 2004). Cognition is information gained from experience and education that includes specific practices, norms, customs, and conventions, including universal facets of culture as well as culture-specific nuances (Ang et al., 2007).

H2: Cognition indicator has a significant relationship with communications of Tehran Neighborhood councils.

\section{Motivation}

The motivation aspect of CI involves a person's interest to learn and function in crosscultural situations with different cultures (Ang et al., 2006; 2007). This facet of CI includes three primary motivators: (i) enhancement (one's will to feel good about himself/herself), (ii) growth (one's will to challenge and improve himself/herself), and (iii) continuality (desire for continuity and predictability in one's life) (Earley et al., 2003, 2006; Ng and Earley, 2004).

H3: Motivation has a significant relationship with communications of Tehran Neighborhood councils 


\section{Behavior}

As mentioned earlier, the final facet of CI is behavior, or the action aspect of the construct. It includes a person's capability to exhibit suitable verbal and non-verbal behaviors when he/she interacts with others from different cultures (Ang et al., 2006, 2007; Earley et. al., 2006), and to normally interact proficiently with individuals from diverse cultural backgrounds (Thomas, 2006). This may also include the inhibition of displaying certain behaviors (Earley and Ang, 2003), and, in some cases, the recognition that not interacting may be appropriate (Thomas, 2006).

H4: Behavior has a significant relationship with communications of Tehran Neighborhood councils.

\section{Network Organizations and Communications}

Network organizations, which are different from previous types of organizations in several respects, are collections of organizations with links that tie them to one another (Snow, Miles, 1992). There are abundant variations on the network organizational forms such as strategic alliances, joint partnerships, research and development consortia, cartels, and large international projects. In the 1980s, plans of many organizations used to depend mostly upon the decisions of other organizations; they noticed that their problems are bigger than they can solve them by themselves. Also they became aware that their attempts to handle environmental contingencies often create unexpected problems (Gray, 1985; Fox, 2008). Furthermore, increased environmental complexity and turbulence led to organizations expanding their boundary-spanning activities in order to include collaboration with other organizations and integrating entities (Buono, 1997). Relationships among organizations have been established since organizations hope to decrease elements of risk and uncertainty by joining other players in a typical market, and to improve their resource level, including both material resources and the information they use to guide their decisions and actions (Powell, 1987).

This was mainly discussed in theories such as Resource Dependence Theory (RDT), and traditional theories of power, which claim that resources are available in an environment and any organization should interact with others in order to gain power, accessing the resources (Davis, Cobb, 2010). Recently, it has been discussed that relationships among organizations could also help them share vital knowledge, which is mainly considered as intellectual capital. This type of knowledge sharing can be termed collaborative commerce, which is normally shared between groups of network organizations. Another dilemma is team work among the individuals working in different organizations of a network and the organizations themselves, which lead their internal information systems to be opened, and improves innovation level (Rockart, 1988; Salamzadeh et al., 2015). These relationships are, basically, used to construct mutual public confidence among organizations themselves and their customers (Stuart, 2000).

The relationships among these network organizations are complex and volatile. Then, one might believe that deriving a universal model of network communications is impossible, or even hard to achieve. A model which elaborates the relationships, communications, and highlights the relevant properties (e.g. see, Oberg,Walgenbach, 2008; Maglajlic, Helic, 2012). Moreover, it might seem unfeasible to make abstractions of micro level interactions to comprehend macro tendencies and directions. Nevertheless, different levels of complexity are considerable. Krackhardt (1994) argues that there are four potential constraints on 
communication and other networks, which are as follows: (i) The Law of N-Squared: in a network organization, the number of possible links raises geometrically with the number of individuals, (ii) The Law of Propinquity: the probability of two people communicating is inversely proportional to the distance between them, (iii) The Iron Law of Oligarchy: the propensity of social systems, even democratic ones, to end up under the control of a few individuals, and (iv) The problem of over embeddedness: habitually individuals are likely to seek out their old standbys, the individuals they have learnt to trust, the ones they depend on, to deal with new problems, even though they might not be the relevant ones (Kim et al., 2006; Fox, 2008; Wellman et al., 2014). In sum, in the existing literature on network organizations, quite a few measures are discussed to differentiate such organizations from bureaucratic ones. Regarding the network organizations, the following hypotheses are proposed:

\section{H5: Roles of individuals in network has a significant relationship with CI. \\ H6: Individuals have a significant relationship with CI.}

\section{H7: Dyads have a significant relationship with CI.}

\section{H8: The whole network has a significant relationship with CI.}

\section{Methodology}

The research model presents critical factors defining cultural intelligence. After interviews with experts of the field, and reviewing the literature, the model is designed (Figure 1). Then a field research is conducted and the required data was gathered from a survey, in which members of Tehran neighborhood councils were the main respondents. Table 1 shows the dimensions and indicators of the study. The population included the members of Tehran neighborhood councils, and thus, random sampling technique was used to determine the required number of samples $(n=136)$. Validity of the model was proved through expert validity. For this purpose, professors, experts, specialist, and experts of the neighborhood council reviewed the questions. For assessing the internal consistency of the questionnaire, Cronbach's Alpha was used that is obtained 0.85 .

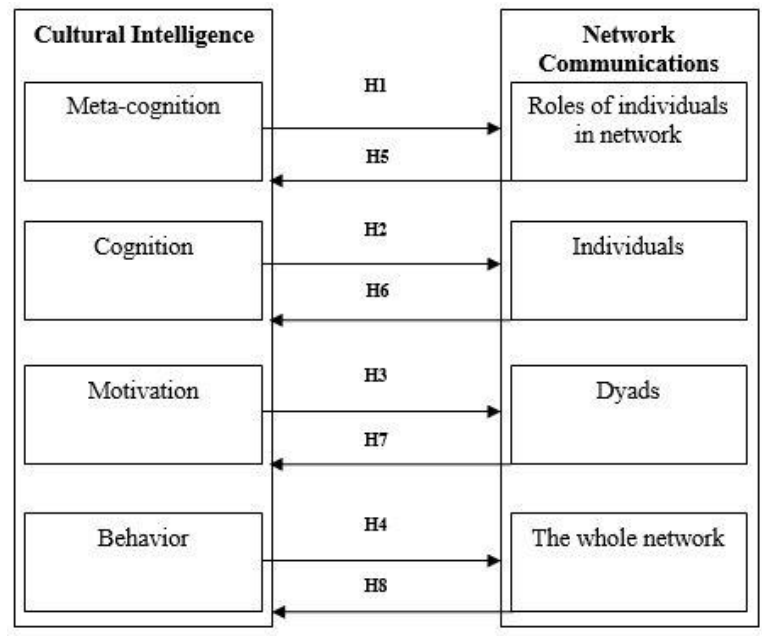

Figure 1: Research model 
Table 1: Dimensions and indicators of communication (source: Albrecht,Bach, 1997; Monge, Contractor, 2001).

\begin{tabular}{||l|l||}
\hline \multicolumn{1}{|c|}{ Dimensions } & \multicolumn{1}{c|}{ Indicators } \\
\hline Roles of individuals in network & $\begin{array}{l}\text { Group members; isolate; bridge, liaison, star, } \\
\text { gate keeper }\end{array}$ \\
\hline $\begin{array}{l}\text { Dimensions of analysis for } \\
\text { individuals }\end{array}$ & $\begin{array}{l}\text { Centrality; connectedness; diversity; } \\
\text { accessibility }\end{array}$ \\
\hline Dimensions of analysis for dyads & $\begin{array}{l}\text { Strength; symmetry; direction; stability; } \\
\text { multiplexity; openness }\end{array}$ \\
\hline $\begin{array}{l}\text { Dimensions of analysis for whole } \\
\text { network }\end{array}$ & $\begin{array}{l}\text { Size; hetrogenity; mode of communication; } \\
\text { density; clustering }\end{array}$ \\
\hline Mata- Cognitive & Planning, Awareness, Checking \\
\hline Cognitive & $\begin{array}{l}\text { Culture-General Knowledge, Context-Specific } \\
\text { Knowledge }\end{array}$ \\
\hline Motivational & $\begin{array}{l}\text { Intrinsic interest, Extrinsic interest, Self- } \\
\text { efficacy to adjust }\end{array}$ \\
\hline Behavioral & $\begin{array}{l}\text { Verbal behavior, Non-verbal behavior, Speech } \\
\text { acts }\end{array}$ \\
\hline \hline
\end{tabular}

\section{Results}

According to demographic data, more than 69 percent of respondents were male. More information is shown in table 2. Descriptive statistic (frequency, mean, standard deviation) is shown in table 3. According to research data from table 3, the factors of Meta-cognitive, cognitive, motivational and behavioral had the highest scores respectively $(3.78,3.6,3.57$, and 3.56) in Tehran neighborhood councils.

Table 2: Demographic data of population

\begin{tabular}{||c|c|c||}
\hline & Number & Percent (\%) \\
\hline \multicolumn{3}{|c|}{ Sex } \\
\hline Male & 93 & 69 \\
\hline Female & 41 & 31 \\
\hline \multicolumn{3}{|c|}{ Education } \\
\hline High school & 21 & 15 \\
\hline Graduate & 32 & 24 \\
\hline Undergraduate & 55 & 42 \\
\hline Master & 19 & 14 \\
\hline PhD & 7 & 5 \\
\hline \multicolumn{3}{|c|}{}
\end{tabular}


Table 3: Measures of variable

\begin{tabular}{|c|c|c|c|c|c|}
\hline Variable & Description & Frequency & Average & $\begin{array}{l}\text { Standard } \\
\text { Deviation }\end{array}$ & $\begin{array}{l}\text { Coefficient } \\
\text { of variation }\end{array}$ \\
\hline \multirow{3}{*}{$\begin{array}{c}\text { Meta- } \\
\text { cognitive }\end{array}$} & $\begin{array}{l}\text { I develop action plans } \\
\text { before interacting with } \\
\text { people from a different } \\
\text { culture }\end{array}$ & 134 & 4 & 1.062 & 0.265 \\
\hline & $\begin{array}{l}\text { I am aware of how my } \\
\text { culture influences my } \\
\text { interactions with people } \\
\text { from different cultures }\end{array}$ & 134 & 4 & 1.053 & 0.263 \\
\hline & $\begin{array}{l}\text { I adjust my } \\
\text { understanding of a } \\
\text { culture while I interact } \\
\text { with people from that } \\
\text { culture }\end{array}$ & 134 & 4.01 & 1.004 & 0.25 \\
\hline \multirow{2}{*}{ Cognitive } & $\begin{array}{l}\text { I can describe the different } \\
\text { cultural value frameworks } \\
\text { that explain behaviors } \\
\text { around the world }\end{array}$ & 134 & 3.93 & 1.092 & 0.277 \\
\hline & $\begin{array}{l}\text { I can describe the ways } \\
\text { that leadership styles } \\
\text { differ across cultural } \\
\text { settings }\end{array}$ & 134 & 3.97 & 1.057 & 0.395 \\
\hline \multirow{3}{*}{ Motivational } & $\begin{array}{l}\text { I truly enjoy interacting } \\
\text { with people from } \\
\text { different cultures }\end{array}$ & 134 & 3.96 & 1.151 & 0.29 \\
\hline & $\begin{array}{l}\text { I value the status I } \\
\text { would gain from living } \\
\text { or working in a different } \\
\text { culture }\end{array}$ & 134 & 4 & 1.038 & 0.259 \\
\hline & $\begin{array}{l}\text { I am confident that I can } \\
\text { persist in coping with } \\
\text { living conditions in } \\
\text { different cultures }\end{array}$ & 134 & 4 & 1.024 & 0.265 \\
\hline \multirow{3}{*}{ Behavioral } & $\begin{array}{l}\text { I change my use of } \\
\text { pause and silence to suit } \\
\text { different cultural } \\
\text { situations }\end{array}$ & 134 & 4 & 1.048 & 0.262 \\
\hline & $\begin{array}{l}\text { I modify how close or } \\
\text { far apart I stand when } \\
\text { interacting with people } \\
\text { from different cultures }\end{array}$ & 134 & 3.99 & 1.070 & 0.27 \\
\hline & $\begin{array}{l}\text { I modify the way I } \\
\text { disagree with others to } \\
\text { fit the cultural setting }\end{array}$ & 134 & 4 & 1.034 & 0.258 \\
\hline
\end{tabular}


Table 4: Variable means

\begin{tabular}{|c|c|c|}
\hline Rank & Dimension & Amplitude \\
\hline $\mathbf{1}$ & Motivational & 3.78 \\
\hline $\mathbf{3}$ & Meta-cognitive & 3.6 \\
\hline $\mathbf{4}$ & Cognitive & 3.57 \\
\hline $\mathbf{5}$ & Behavioral & 3.56 \\
\hline
\end{tabular}

As shown in table 5, effect of volume external communication had the highest rank with mean rank of 4.3 and effect of Volume external communication had the lowest rank with mean rank of 3.49 mean distribution of opinions of respondents to dimensions of cultural intelligence and questions of research in turn are shown in table 5 and 6. In order to determine the relationship between research variables, the Pearson correlation test was utilized. As indicated in table 6 , there was a direct and significant relationship between Meta-cognition and communications ( $\mathrm{r}=0.81$ ), and Cognition with communications ( $\mathrm{r}=0.41)$, and Motivation with communications $(\mathrm{r}=0.368)$ and Behavior with communications $(\mathrm{r}=0.726)$. Also, there was a direct and significant relationship between Roles of individuals in network with CI ( $\mathrm{r}=0.311)$ and Dimensions of analysis for individuals with CI $(r=0.728)$ and Dimensions of analysis for dyads with CI $(r=0.468)$ and Dimensions of analysis for whole network with CI $(r=0.582)$.

Table 5: Mean distribution of opinions of respondents to questions of research

\begin{tabular}{|c|c|c|c|}
\hline Rank & $\begin{array}{c}\text { No. of } \\
\text { question }\end{array}$ & Description & Score \\
\hline 1 & 21 & $\begin{array}{l}\text { Effect of Volume external communication, on cultural attitude of } \\
\text { staff }\end{array}$ & 4.3 \\
\hline 2 & 6 & Non-verbal communication in other cultures & 3.77 \\
\hline 3 & 15 & Type of communication within the organization & 3.64 \\
\hline 4 & 14 & $\begin{array}{l}\text { Effect of Responsibilities and roles individuals in of } \\
\text { organizational communication, on cultural perceptions }\end{array}$ & 3.62 \\
\hline 5 & 19 & $\begin{array}{l}\text { Effect the size and number of members, on cultural attitudes of } \\
\text { staff }\end{array}$ & 3.61 \\
\hline 6 & 7 & Change in verbal behavior & 3.59 \\
\hline 7 & 10 & $\begin{array}{l}\text { Changes in speaking rate appropriate to different cultural } \\
\text { situations }\end{array}$ & 3.58 \\
\hline 8 & 18 & $\begin{array}{l}\text { Effect of communication with the same organization on reducing } \\
\text { or increasing cultural understanding staff }\end{array}$ & 3.58 \\
\hline 9 & 8 & Change in Nonverbal behavior & 3.56 \\
\hline 10 & 22 & $\begin{array}{l}\text { Effect of size and the number of members in the organization on } \\
\text { the employees' motivation }\end{array}$ & 3.56 \\
\hline 11 & 23 & $\begin{array}{l}\text { Effect of Lack Relations with similar organizations in reducing or } \\
\text { increasing employees' motivation }\end{array}$ & 3.56 \\
\hline 12 & 16 & $\begin{array}{l}\text { Effect of Variety tasks and roles in the organization on the culture } \\
\text { of the organization }\end{array}$ & 3.55 \\
\hline 13 & 17 & $\begin{array}{l}\text { Effect of Lack communication with similar organizations in } \\
\text { reducing or increasing cultural perception staff }\end{array}$ & 3.55 \\
\hline 14 & 9 & use of hesitated and quiet suit different cultural situations & 3.54 \\
\hline 15 & 11 & interested in communicating with people from different cultures & 3.53 \\
\hline 16 & 13 & Effect of organizational status and cultural perception & 3.51 \\
\hline 17 & 12 & feedback of communicating with people from different cultures & 3.5 \\
\hline 18 & 20 & $\begin{array}{l}\text { effect of Volume external communication, on cultural attitude of } \\
\text { staff }\end{array}$ & 3.49 \\
\hline
\end{tabular}


A total of 23 questions were asked about the relationship between cultural intelligence and network communication. The respondents were asked to select their responses by choosing the number that best applied to them. The options were presented on a 5 point Likert scale with $1=$ very low, $2=$ low, $3=$ average, $4=$ high, $5=$ too high. The questions for cultural intelligence were divided into four sections: meta-cognitive, cognitive, motivation and behavioral and questions for cultural intelligence were divided into four sections: Roles of individuals in network, Dimensions of analysis for individuals, Dimensions of analysis for dyads, Dimensions of analysis for whole network. Of the eight sections, it may be observed that the mean scores ranged between 3.49 and 4.3. This suggests that the respondents' scores on average were between being average and too high with statements of items. The question with the highest mean score asked" Non effect of Volume external communication, on cultural attitude of staff" (Q21)." effect of Volume external communication, on cultural attitude of staff"(Q22) had the lowest mean score.

Table 6 summarizes the results of our survey that all of hypotheses are accepted with level of confidence $\% 95$ and coefficient of correlation between 0.311 for $\mathrm{H} 5$ to 0.808 for $\mathrm{H} 1$. This research has 8 hypotheses (hypotheses numbers 1 to 4 are about relationships between variables of "cultural intelligence" and "communications", while hypotheses number 5 to 8 are about the relationships between "network communications" and "cultural intelligence". As shown in table 6, all the hypotheses are accepted.

\section{Table 6: Summary of results}

\begin{tabular}{||c|c|c|c|c||}
\hline \multicolumn{1}{|c|}{ Hypothesis } & $\begin{array}{c}\text { level of } \\
\text { confidence }\end{array}$ & Sig & $\begin{array}{c}\text { coefficient of } \\
\text { correlation }\end{array}$ & Results \\
\hline $\begin{array}{l}\text { H1: Meta-cognition has a significant } \\
\text { relationship with communications of Tehran } \\
\text { Neighborhood councils }\end{array}$ & -0.95 & 0.00 & -0.808 & Accepted \\
\hline $\begin{array}{l}\text { H2: Cognition indicator has a significant } \\
\text { relationship with communications of Tehran } \\
\text { Neighborhood councils }\end{array}$ & -0.95 & 0.00 & -0.41 & Accepted \\
\hline $\begin{array}{l}\text { H3: Motivation has a significant relationship } \\
\text { with communications of Tehran } \\
\text { Neighborhood councils significant relationship }\end{array}$ & -0.95 & 0.00 & -0.368 & Accepted \\
\hline $\begin{array}{l}\text { H4: Behavior has a sign of Tehran } \\
\text { with communications } \\
\text { Neighborhood councils }\end{array}$ - 0.95 & 0.00 & -0.726 & Accepted \\
\hline $\begin{array}{l}\text { H5: Roles of individuals in network has a } \\
\text { significant relationship with CI }\end{array}$ & -0.95 & 0.00 & -0.311 & Accepted \\
\hline $\begin{array}{l}\text { H6: Dimensions of analysis for individuals } \\
\text { has a significant relationship with CI }\end{array}$ & -0.95 & 0.00 & -0.728 & Accepted \\
\hline $\begin{array}{l}\text { H7: Dimensions of analysis for dyads has a } \\
\text { significant relationship with CI }\end{array}$ & -0.95 & 0.00 & -0.468 & Accepted \\
\hline $\begin{array}{l}\text { H8: Dimensions of analysis for whole } \\
\text { network has a significant relationship with } \\
\text { CI }\end{array}$ & -0.95 & 0.00 & -0.582 & Accepted \\
\hline
\end{tabular}


Table 7: Relationship between dimensions of cultural intelligence and network communication

\begin{tabular}{|l|c|c|c|c||}
\hline \multicolumn{1}{|c|}{ Dimensions } & $\begin{array}{c}\text { Meta } \\
\text { cognitive }\end{array}$ & Cognitive & Motivational & Behavioral \\
\hline Roles of individuals in network & 0.098 & 0.276 & 0.287 & 0.142 \\
\hline $\begin{array}{l}\text { Dimensions of analysis for } \\
\text { individuals }\end{array}$ & 0.254 & 0.187 & 0.216 & 0.376 \\
\hline Dimensions of analysis for dyads & 0.210 & 0.198 & 0.216 & 0.376 \\
\hline $\begin{array}{l}\text { Dimensions of analysis for whole } \\
\text { network }\end{array}$ & 0.181 & 0.098 & 0.154 & 0.186 \\
\hline
\end{tabular}

The means, standard deviations and correlations among the variables in the study are presented in Table 7. Correlations in general reflect the expected relationships between the components of cultural intelligence and network communications. Among dimensions of cultural intelligence, behavioral has highest correlation with dimensions of network communications (Dimensions of analysis for individuals, Dimensions of analysis for dyads). Also Meta cognitive has lower correlation (Roles of individuals in network, Dimensions of analysis for whole network). However cognitive dimension has low correlation with Dimensions of analysis for whole network (0.098), looking at the research hypothesis about the correlations among various dimensions of cultural intelligence we can get all dimensions of CI has significant relation with dimensions of network communications.

\section{Conclusion}

In this paper, the relation of cultural intelligence and network communications was analyzed. Findings show that cultural intelligence is a significant factor in shaping network communications. Confirming the main hypothesis of this study also represents the existence of a positive and meaningful relation between cultural intelligence and network communications. Moreover, results of Pearson's correlation test indicate that there is a positive relationship between the cultural intelligence as an independent variable and network communications (dependent variable) in Tehran neighborhood councils. Then, by increasing the cultural Intelligence of members, members' communications will be increased and cultural intelligence is an excellent criterion to be taken into account for the members and managers communications. Moreover, motivational CI and the behavioral CI are highly correlated with communication indicators. Also, the results show that members of Tehran neighborhood councils need to acquire and improve their cultural intelligence human skills in order to fullfill their extraorganizational tasks and increase their communications with costumers or other members.

By the way, findings of this research are in line with similar research works which show a positive relationship between CI and networks, such as Monge and Contractor (2001), Earley et al. (2006), Lugo (2007), etc. Furthermore, in organizations which have a high cultural variety and complexity, cultural intelligence helps the organization managers compromise with the different cultural and value qualities and characteristics of their members such as Tehran neighborhood councils. In active organizations in multicultural environments, cultural intelligence beside operational skills could guarantee the organization success, so choosing, educating, and evaluating the managers in such organizations shouldn't be limited to technical and scientific abilities, and the ability to communicate efficiently and specially cultural intelligence should be considered as an effective criterion in employing managers in such organizations. Hiring managers and employees with high cultural intelligence in organizations, it would be prevented to load reinforcing cultural intelligence costs (Ang et al., 2006, 119). 
Also the results of this study show that cultural intelligence could be the answer to many problems and issues in different socio-cultural contexts. Considering this kind of intelligence especially in network organizations which has a high ethnic and cultural variety could be very useful for improving employee-managers communications. In addition, evaluating and advancing cultural intelligence in organizations, while keeping the present cultural capitals in organizations, cause improving their communications in network environments. Thus to promote this kind of intelligence in organizations, some suggestion are presented for managers including selfreviewing of managers' cultural knowledge, increasing awareness regarding cross-cultural interactions, identifying different cultures, respecting other cultures, engaging in other cultures, and paying attention to the possibility of cross-cultural interactions in real conditions.

\section{Reference}

[1] Albrecht, T.L.,Bach, B.W. (1997). Communication in Complex Organizations: A Relational Approach. Fort Worth, TX: Harcourt Brace.

[2] Alidoust, A. R.,Homaei, M. B. (2012). Analysis the effects of Cultural Intelligence on Knowledge Management Practice (Case study: Higher Education Institutions). Interdisciplinary Journal of Contemporary Research in Business, 3(10), 633.

[3] Ang, S., Dyne, L., Koh, C., Ng, K., Templer, K., Tay, C., et al. (2007). Cultural Intelligence: Its measurement and effects on cultural judgment and decision making, cultural adaptation, and task perfromance. Management and Organization Review

[4] Ang, S., Van Dyne, L.,Koh, C. (2006). Personality correlates of the four-factor model of cultural intelligence. Group \& Organization Management, 31(1), 100-123. doi: $10.1177 / 1059601105275267$

[5] Ang, S., Van Dyne, L., Koh, C., Ng, K. Y., Templer, K. J., Tay, C.,Chandrasekar, N. A. (2007). Cultural intelligence: Its measurement and effects on cultural judgment and decision making, cultural adaptation and task performance. Management and Organization Review, 3(3), 335-371.

[6] Arquilla, J.,Ronfeldt, D. (2001). The advent of netwar (revisited). In D. Ronfeldt (Ed.), Networks and netwars: The future of terror, crime and militancy: 1-24. Santa Monica, CA: Rand Corporation.

[7] Baker, W. E. (1992). The network organization in theory and practice. In R. C. Eccles (Ed.), Networks and organizations: Structure, form and action: 397-429. Boston, MA: Harvard Business School Press

[8] Buono, A. F. (1997). Enhancing strategic partnerships: Intervening in network organizations. Journal of Organizational Change Management, 10(3), 251-266.

[9] Daryani, M. A., Salamzadeh, Y., Salamzadeh, A.,Sharafi, F. (2011c). An Analysis of the Current Gaps in Social Entrepreneurship in Iran: Shackled Feet. In 1st International Conference on Management, Innovation and Entrepreneurship, Shiraz, Iran.

[10] Davis, G. F.,Cobb, J. A. (2010). Resource dependence theory: Past and future. Research in the Sociology of Organizations, 28(1), 21-42.

[11]Earley, P. C.,Ang, S. (2003). Cultural intelligence: Individual interactions across cultures. Stanford University Press.

[12] Earley, P. C.,Peterson, R. S. (2004). The elusive cultural chameleon: Cultural intelligence as a new approach to intercultural training for the global manager. Academy of Management Learning \& Education, 3(1), 100-115. 
[13]Earley, P. C., Ang, S., Tan, J.-S. (2006). CI: Developing cultural intelligence at work. Palo Alto, CA: Stanford University Press.

[14] Ford, J. K., Smith, E. M., Weissbein, D. A., Gully, S. M.,Salas, E. (1998). Relationships of goal orientation, metacognitive activity, and practice strategies with learning outcomes and transfer. Journal of applied psychology, 83(2), 218.

[15] Fox, S. (2008). Ontological uncertainty and semantic uncertainty in global network organizations. VTT working papers.

[16] Gomory, R. E.,Hu, T. C. (1964). Synthesis of a communication network. Journal of the Society for Industrial \& Applied Mathematics, 12(2), 348-369.

[17] Gorji, M.,Ghareseflo, H. (2011, December). The survey of relationship between cultural intelligence and emotional intelligence with employee's performance. In 2011 International Conference on E-business, Management and Economics (pp. 175-180).

[18] Gray, B. (1985). Conditions facilitating interorganizational collaboration. Human Relations, 38, 911.936.

[19] Ibarra, H. (1992). Structural alignments, individual strategies, and managerial action: Elements toward a network theory of getting things done. In R. G. Eccles (Ed.), Networks and organizations: Structure, form and action: 165-188. Boston, MA: Harvard Business School Press.

[20] Kanten, P. (2014). The effect of cultural intelligence on career competencies and customer-oriented service behaviors. Journal of the School of Business Administration, Istanbul University, 43(1), 100-119.

[21] Keung, K. E.,Rockinson-Szapkiw, J. A. (2013). The relationship between transformational leadership and cultural intelligence: A study of international school leaders. Journal of Educational Administration, 51(6), 836-854.

[22] Kim, T. Y., Oh, H.,Swaminathan, A. (2006). Framing interorganizational network change: A network inertia perspective. Academy of Management Review, 31(3), 704-720.

[23] Krackhardt, D. (1994). Constraints on the interactive organization as an ideal type. In: Heckscher, C. and Donnellon, A. (eds.) The post-bureaucratic organization: New perspectives on organizational change, 211.222. Thousand Oaks, CA: Sage.

[24]Lugo, M. (2007). An Examination of Cultural and Emotional Intelligences in the Development of Global Transformational Leadership skill. Dissertation for the degree of doctor of philosophy.

[25] Maglajlic, S.,Helic, D. (2012). How do social networks influence learning outcomes? A case study in an industrial setting. Interactive Technology and Smart Education, 9(2), 74-88.

[26] Monge, P.R., Contractor, N.S. (2001). Emergence of communication networks. In: Jablin, F.M. and Putnam, L.L. (eds.) Newhandbook of organizational communication, 440.502. Newbury Park, CA: Sage.

[27] Moody, M.C. (2007). Adaptive behavior in intercultural environments: The relationship between cultural intelligence factors and BIG five personality traits. Dissertation for the degree of doctor.

[28] Ng, K.-Y., Earley, P. C. (2006). Culture + intelligence: Old constructs, new frontiers. Group \& Organization Management, 31(1), 4-19.

[29] Nohria, N.,Eccles, R. G. (2000). Face-to-face: Making network organizations work. In R. G. Eccles (Ed.), Networks and organizations: Structure, form and action: 288-308. Boston, MA: Harvard Business School Press.

[30] Oberg, A.,Walgenbach, P. (2008). Hierarchical structures of communication in a network organization. Scandinavian Journal of Management, 24(3), 183-198. 
[31] Offermann, L. R.,Phan, L. U. (2002). Culturally intelligent leadership for a diverse world. Multiple intelligences and leadership, 187-214.

[32] Powell, W.W. (1987). Hybrid organizational arrangements. California Management Review, 30 (1), 67.87.

[33] Radovic Markovic,M., Baltezarevic,V., Baltezarevic,R., Markovic,SD.(2014). Virtual organisation and motivational business management, Maribor : Alma Mater Europea Evropski center ; Beograd : Institute of Economic Sciences.

[34] Radovic Markovic,M.,Vukotic,V.,Krumova,A.(2014).Work motivation:Comparative Analysis between Serbia and Bulgaria ,International Review, 1-2,2014.

[35] Rockart, J.F. (1998). Towards survivability of communication: intensive new organizational forms. Journal of Management Studies, 35, 417.420.

[36] Ronfeldt, D.,Arquilla, J. (2001). Networks, netwars and the fight for the future. First Monday, 6(10).

[37] Ryan, A., Kajzer Mitchell, I., \& Daskou, S. (2012). An interaction and networks approach to developing sustainable organizations. Journal of Organizational Change Management, 25(4), 578-594.

[38] Salamzadeh, A.,Salamzadeh, Y. (2011b, June). What is Social Entrepreneurship?. In 1st International Conference on Business, Strategy and Management, Kolkata, India ISBN (pp. 81-87912).

[39] Salamzadeh, A., Azimi, M. A.,Kirby, D. A. (2013). Social entrepreneurship education in higher education: insights from a developing country. International Journal of Entrepreneurship and Small Business, 20(1), 17-34.

[40] Salamzadeh, A., Farsi, J. Y., Motavaseli, M., Radovic Markovic, M.,Kesim, H. K. (2015). Institutional factors affecting the transformation of entrepreneurial universities. International Journal of Business and Globalisation, 14(3), 271-291.

[41] Salamzadeh, A., Salamzadeh, Y.,Nejati, M. (2011a, October). Social entrepreneurship: analyzing literature and proposing a comprehensive model. In Proceedings of the 9th Asian Academy of Management International Conference.

[42] Snow, C. C.,Miles, R. E. (1992). Causes for failure in network organizations. California management review, 34(1), 53-57.

[43] Stuart, T.E. (2000). Interorganizational alliances and the performance of firms: a study of growth and innovation rates in a high technology industry. Strategic Management Journal, 21, 791-881.

[44] Thomas, D. C. (2006). Domain and Development of Cultural Intelligence The Importance of Mindfulness. Group \& Organization Management, 31(1), 78-99.

[45] Triandis. H.C. (2006). Cultural intelligence in Organizations . Group and Organization Management, Vol.31, No.1, pp. 20-26

[46] Wellman, B., Dimitrova, D., Hayat, Z., Mo, G. Y.,Smale, L. (2014). Networking scholars in a networked organization. In Contemporary Perspectives on Organizational Social Networks (pp. 479-497). Emerald Group Publishing Limited.

\section{Article history:}

- $\quad$ Received 20 March 2016

- $\quad$ Accepted 26 April 2016 